\title{
BRENTANO AND MEDIEVAL ONTOLOGY
}

\author{
Brentano and Medieval Ontology \\ Brentano and Medieval Ontology
}

LAURENT CESALII

\begin{abstract}
Since the first discussion of Brentano's relation to (and account of) medieval philosophy by Spiegelberg in 1936, a fair amount of studies have been dedicated to the topic. And if those studies focused on some systematic issue at all, the beloved topic of intentionality clearly occupied a hegemonic position in the scholarly landscape. This paper considers the question from the point of view of ontology, and in a twofold perspective: What did Brentano know about medieval ontology and what kind of access did he have to that material (section 1)? What kind of use did Brentano make of medieval material in his own philosophy, and with what kind of results (section 2)?
\end{abstract}

Keywords: Brentano. Medieval Ontology, Intentionality.

Resumen: Desde la primera discusión de la relación de Brentano y la filosofía medieval por Spiegelberg en 1936, se han dedicado una cantidad considerable de estudios cerca del tema. Y si esos estudios se centraron en algún tema sistemático, el amado tema de la intencionalidad claramente ocupó una posición hegemónica en el panorama académico. Este trabajo considera la pregunta desde el punto de vista de la ontología, y en una doble perspectiva: ¿Qué sabía Brentano sobre la ontología medieval y qué tipo de acceso tenía a ese material (sección 1)? ¿Qué tipo de uso hizo Brentano de material medieval en su propia filosofía, y con qué tipo de resultados (sección 2)?

Palabras-Clave: Brentano, Ontología Medieval. Intencionalidad.

Resumo: Desde a primeira discussão sobre a relação de Brentano com a filosofia medieval feita por Spiegelberg, em 1936, uma boa quantidade de estudos foi dedicada ao tema. E se esses estudos focalizaram alguma questão sistemática, o tópico da intencionalidade claramente ocupou uma posição hegemônica na paisagem acadêmica. Este artigo considera a questão do ponto de vista da ontologia e, em uma dupla perspectiva: O que Brentano sabia sobre a ontologia medieval e que tipo de acesso ele tinha a esse material (seção 1)? Que tipo de uso Brentano fez do material medieval em sua própria filosofia e com que tipo de resultados (seção 2)?

Palavras-Chave: Brentano, Ontologia Medieval, Intencionalidade.

Since the first discussion of Brentano's relation to (and account of) medieval philosophy by Spiegelberg in 1936, a fair amount of studies have been dedicated to the topic. And if those studies focused on some systematic issue at all, the beloved topic of intentionality clearly occupied a hegemonic position in the scholarly landscape2. The following pages consider the question from the point of view of ontology, and in a twofold perspective: What did Brentano know about medieval ontology and what kind of access did he have to that material (section 1)? What kind of use did Brentano make of medieval material in his own philosophy, and with what kind of results (section 2)?

\section{Elements from Brentano's intellectual biography}

1 Parts of this paper were presented in 2016 at the workshop 'The Schoo of Brentano and the Rise of Scientific Philosophy' in Utrecht and at the international conference 'Intentionality and Consciousness. From Austrian to Contemporary Philosophy of Mind' in Fribourg. We thank the participants for their comments, especially Guillaume Fréchette, Dominik Perler and Peter Andras Varga.

2 Gilson 1939; Hedwig 1978, 1979, 1992, 2012; Libera 2007, 2008 , 2011; Marras 1974; McDonnell 2006a, 2006b, Münch 2004; Spiegelberg 1936, 1976. On intentionality in the Middle Ages, see Perler 2002.

\section{a. Brentano's academic training (1855-1866)}

As a young man stemming from a respectable upper middle-class, catholic family of late $19^{\text {th }}$-century Germany, Brentano received a well-balanced and complete education ${ }^{3}$. After the Gymnasium in Aschaffenburg, Brentano begins in 1855/56 his academic formation in the Lyzeum (something like a Faculty of humanities) of the same town with the study of philosophy and mathematics. The next year, he begins his training as a theologian in Munich (1856/58) and then in Würzburg (1858) and Berlin (1858/59) under the direction of Friedrich Adolf Trendelenburg who reinforces his interest in Aristotle and directs it more specifically to psychology. The next station is Münster (1859/60), and it is a crucial one with respect to Brentano's acquaintance with medieval thought although, as theologian, he must have been already familiar with at least some aspects of the thought of major scholastic figures, such as Thomas Aquinas or John Duns Scotus. In Münster, Brentano attends the lectures of Franz Jakob Clemens, a mandatory part of the theologians' cursus.

3 On Brentano's biography, see Baumgartner, Burkard 1990 and Kraus 1976. Franz Brentano was born 1838 in Marienberg am Rhein, and died in Zürich in 1917. 
Clemens, together with Hermann Ernst Plassmann and Joseph Kleutgen, belongs to the founders of German Neo-Scholasticism ${ }^{4}$. The program of this intellectual movement is characterized not by a kind of nostalgic return to medieval philosophy, but by the aim of "getting over contemporary philosophy (and theology) in drawing on scholastic, and in particular ... on Aquinas' thought" . Clemens is the anonymous author of the manifest "Unser Standpunkt in der Philosophie", published in the issue 39.2 of the journal Der Katholik (1859). There, along lines that bear instructive similarities with Aquinas' methodological strategy in the prologue of his Summa contra gentiles, Clemens defends the idea that since there is only one truth, and since revealed truth enjoys epistemic dominance by definition, any argument concluding against the authority of the Church must be mistaken. Philosophy is indeed the ancilla theologiae, meaning: philosophy is necessary for theology and has the function to guide human beings to the realm of supernatural knowledge, i.e. that of theology. Thus, the gist of Clemens' Neo-Scholasticism can perhaps be expressed in saying that it consists in insufflate scholastic spirit in contemporary philosophy. It is not implausible that Brentano's contact with Clemens and thus with emerging Neo-Scholasticism contributed to his thirst for renewal and rehabilitation of philosophy in the post-Hegelian German-speaking world.

At the same time, Brentano's exchanges with the philosopher and theologian Christoph Bernhard Schlüter-whom he met several times in Berlin before coming to Würzburg, and who, after the early death of Clemens in 1862, commented on Brentano's dissertation on the several senses of being in Aristotle ${ }^{6}$-show that he also took his distances from the Neo-Scholastic line of thought. Thus, he deeply disagreed with Schlüter's reaction to his interpretation of Aristotle. Schlüter lists the (many) points where Brentano's (and the protestant Trendelenburg's) Aristotle threatens core tenets of Christian doctrine, e.g. on the status of the category of relation, for example, that should not be considered the weakest kind of being7. In his own words, Schlüter "speaks for Plato and Saint Augustine" (meaning: against Brentano's Aristotle). Brentano cannot accept such an attitude, namely Schlüter's (mistakenly) indicting Aristotle.

Brentano's reply is surprising and highly interesting. He does not endeavour to show that his reading of Aristotle is not incompatible with Christian doctrine. Nor does he renounce to any form of apo-

4 Coreth 1988; Kluxen 1988; Walter 1988. The successor of Clemen in Münster was Albert Stöckl, author of a monumental Geschichte der Philosophie des Mittelalters (1864-1866), one of Brentano main sources in his own writings on scholastic thought.

5 Walter 1988, 133

6 See Nettesheim 1962 and the two letters of Brentano to Schlüter of 1861 and 1863. Brentano received his doctor title in Tübingen in 1862 (in absentia, however, for at that time, he was in residence at the Dominican monastery in Graz).

7 Schlüter's letter to Brentano (11.12.1862): "Wenn S. 152 das pros $t$ die schwächste unter den Kategorien genannt wird, so ist das im Ohre eines Christen eine schreckliche Barbarei, da in diese Kategorie ja die ganze Religion fällt und unser ewiges Heil oder Verwerfung lediglich davon abhängt, wie wir zu Gott stehen, wie er zur Welt und uns." (Nettesheim 1962, 292).

8 Ibid, 293. logy. Instead, he claims to have found "a means to reach the goal of a defence without having to go all its painstaking way"'. That strategy of Brentano's is interesting because of its high relevance with respect to his later conception of the history of philosophy. It takes as a starting point a presupposition that is plainly in line with Clemens methodological principle: there is only one philosophy, for there is only one wisdom, as there is only one truth and only one divinity. Thus, for example, Plato's and Aristotle's philosophies are just one and the same philosophy, to the effect that there is no point in trying to harmonize or reconcile them; only Platonists and Aristotelians can seek for harmonization, for it is only in interpretation (that is in Platonism vs. in Plato or in Aristotelianism vs. in Aristotle that one can step away from true philosophy $)^{10}$. Now, if that is true, then Aristotle simply cannot contradict Christian doctrine-in fact, no correctly developed philosophy can do so. The conclusion, then, is obvious: interpreters who see in Aristotle's philosophy a threat for Christian doctrine do not interpret Aristotle correctly. And such is the case, according to Brentano, of most contemporary interpreters (including, as one might suppose, Schlüter himself ${ }^{11}$.

There is, however, something like a difference of respective impact between Plato's and Aristotle's philosophies. Whereas the former was such as to yield a genial pupil like Aristotle, the latter remained deprived of a comparable successor until the $13^{\text {th }}$ century and the upcoming of Thomas Aquinas. We have in this letter of 1863, one of the early manifestations of Brentano's theory of the four phases of the history of philosophy - a theory elaborated as early as $1860^{12}$, further developed in his Würzburg lectures on the history of philosophy of the years 1866-1870, and most famously (though not exclusively) in printed form in his conference of $1895 \mathrm{On}$ the Four Phases of Philosophy and its Present State.

The next stations of Brentano's intellectual education were the Dominican Monastery of Graz (1862) where he could not find any appropriate master, the university of Munich (1863) where he pursued his study of theology, and finally Würzburg were he became a catholic priest (1864) after having attended the seminary. Two years later (1866)

\footnotetext{
Brentano's letter to Schlüter (16.02.1863), in Nettesheim 1962, 294 "Jetzt aber habe ich vielleicht ein Mittel gefunden, wodurch der Zweck einer Vertheidigung, ohne ihren mühevollen Weg zu betreten, erreicht werden kann."

10 Brentano's letter to Schlüter, 16.02.1863, in Nettesheim 1962, 294 295: "Die Platonische und Aristotelische Philosophie also sind ein und dieselbe. ... Eines aber glaube auch ich behaupten zu dürfen, dass wenn nicht Plato und Aristoteles, doch der Platoniker und Aristoteliker sich recht woh vereinigen lassen. ... Der Aristoteliker muss an Aristoteles', der Platoniker mehr an Platos Lehrsätzen im Einzelnen Änderungen sich erlauben.'

11 Brentano's letter to Schlüter, 02.06.1861, in Nettesheim 1962, 287the letter is written almost two years before the addressee had the opportunity to read Brentano's dissertation, and thus, to react to it. Nonetheless, one can easily imagine that in 1863, Brentano would not have hesitated to count Schlüter among those recent interpreters of Aristotle who make his thought only more difficult to understand instead of clarifying it: "Sonst arbeite ich ziemlich fleissig and meiner Abhandlung [i.e. the dissertation of 1862] und habe auch in der letzten Zeit wieder viel im Aristoteles studiert, von dem ich, wenn ich seine Lehre von Neueren dargestellt lese, immer mit einer geringeren, wenn ich aber seine eignen Schriften studiere, jedesmal mit einer höheren Meinung weggehe."
}

12 See Antonelli $2001,140$. 
he began his teaching as Privatdozent in philosophy at the university of the same town. Two works are linked with Brentano's Habilitation: the 24 (Latin) theses defended in front of the Faculty and a dissertation on Schelling, "Darstellung und Kritik der Lehre Schellings in den drei Stadien" (both published in Brentano 1929). Brentano abandoned the priesthood in 1873, after having rejected the dogma of papal infaillibility ${ }^{13}$.

\section{b. Brentano's (relevant) writings}

Although scholastic thought is (more or less explicitly) present throughout Brentano's worksto give just one (but famous) example, one can recall footnote 3 of the Psychology from an Empirical Standpoint, II.l, §5, where, besides Aristotle, Philo of Alexandria and Augustine, medieval figures such as Anselm of Canterbury and Thomas Aquinas are called in support of Brentano's identification criterion for all mental phenomena-some among his published works stand out with respect to the issue tackled in this chapter, namely his dissertation Von der mannigfachen Bedeutung des Seienden nach Aristoteles (1862), his chapter "Geschichte der kirchlichen Wissenschaften” in Möhler's Kirchengeschichte (1867), and his Geschichte der mittelalterlichen Philosophie im christlichen Abendland a work published only in 1980 but going back to the Würzburg lectures on the history of philosophy ${ }^{14}$.

i) The dissertation of 1862. Brentano's first book is a work on ontology; not in the sense of providing a catalogue of what there is in the world, but rather in that of spelling out the different meanings the word 'being' has according to Aristotle. At first sight, medieval thought is not all over the place in the book: Thomas Aquinas is mentioned by name once (and indirectly) in a significant quote from Giovanni Pico della Mirandola: "Sine Thoma mutus esset Aristoteles" "Without Thomas, Aristotle would be mute") ${ }^{15}$, a (long) passage from his Sententia super Metaphysicam (c.1271) is quoted ${ }^{16}$, one allusion is made to his commentary on the Physics ${ }^{17}$, and William of Ockham is mentioned (and paraphrased) once ${ }^{18}$.

However, as Antonelli and Sauer have shown in their monographic introduction to the new edition of the 1862 dissertation, Brentano offers something like a "medievalized" but also (and as a consequence) "neoplatonizing" reading of Aristotle ${ }^{19}$ : it is "medievalized" because it makes use of a notion of analogy that is foreign to Aristotle's (but not to Aquinas') thought; it is "neoplatonizing" because it addresses the problem of the nature of the Aristotelian categories in the frame of a vertically hierarchized world governed by the (Platonic) principle of parti-

13 For biographical information on Brentano, see again Baumgartner, Burkard 1990 and Kraus 1976.

14 For the significance of scholastic thought in Brentano's (early) philosophy, see Antonelli \& Sauer 2015, esp. XI-XVII and LIX-LXVIII.

15 Brentano 1862/2015, 181/163.

16 Brentano 1862/2015, 181-182/163-164

17 Brentano 1862/2015, 182/165.

18 Brentano 1862/2015, 192-193/173

19 Antonelli \& Sauer 2015, XXX-XL. cipation $^{20}$. Along the same lines, and interestingly enough, in the 1862 dissertation, Brentano turns out to be quite positive with respect to Plotinus' philosophy, an attitude that will be radically different some years later ${ }^{21}$.

As its title says, Brentano's first book is dedicated to shed some light on Aristotle complex notion of being: "the unqualified term 'being' has several meanings" (Metaphysics, $\Delta, 2$ )-but how are those meaning exactly related? The dissertation provides a detailed answer to that question. In Metaphysics $\Delta$, 7, Aristotle distinguishes four meanings of the term 'being': being in an accidental sense (or by coincidence, e.g. a man's being musical, which is not being per se), and three kinds of being per se, namely being in the sense of the categories (e.g. the being of substances and of their accidents) ${ }^{22}$, being as being true (e.g. the being true of a statement), and being in potency or in act (e.g. the being wise in merely possessing some knowledge vs. using it). Now, Brentano's central thesis is that one of those four senses-namely being in the sense of the categories-is fundamental with respect to the three others ${ }^{23}$. More precisely, and since every accident is existentially dependent on a substance, substance itself (that is: the first of the categories) is being in the most fundamental sense. Consequently-and this is the very last point made by Brentano in the dissertation-substance is also the proper object of the science of being as such, namely of metaphysics ${ }^{24}$.

The works is divided into five, unequal chapters. After a first brief presentation of the four Aristotelian meanings of being, Brentano devotes one chapter to each of them in a sequence going from the less to the more fundamental: being in an accidental sense (c. 2), being as being true (c. 3), being in potency and being in act (c.4), and being in the sense of the categories (c. 5). In accordance with Brentano's main thesis, this last chapter is by far the longest, and it is in those pages that we find the only explicit mentions of medieval authors in the whole work. Those references (to Aquinas, to Ockham, as we saw above) aim at supporting Brentano's claim that Aristotle's list of categories is the result of a linguistically guided process of ontological deduction. Brentano construes his own posi-

20 Antonelli \& Sauer 2015, XXXVIII: "Brentanos Interpretation der Aristotelischen Ontologie weist also eindeutig platonisierende Züge auf, die ihm durch seinen Zugang zu Aristoteles durch den Filter seiner scholastischen bzw. Thomistischen Ausbildung vermittelt wurden."

21 Brentano agrees with Plotinus' claim that Aristotle's ontology (i.e. the categories) is incomplete, for it is unable to integrate pure intelligible (i.e. divine) being, thus yielding an unbridgeable gap between ontology and theology. Here also, the medieval-neoplatonizing world view offers a way out For Brentano's acerb criticism of Plotinus' philosophy, see Brentano 1876. 22 The being of accidents is per se (i.e. not being in an accidental sense) because they are genuine ontological categories and have a definite cause. Being in accidental sense is rather a statistical category and does not have a definite cause. See Aristotle, Met. $\Delta, 30$ (transl. Ross): "We call an accident that which attaches to something and can be truly asserted, but neither of necessity, nor usually, e.g. if one in digging a hole for a plant found a treasure. ... therefore there is no definite cause for an accident, but a chance cause, i.e. an indefinite one."

23 Being in the accidental sense cannot be fundamental because it lacks any definite cause; being in the sense of being true cannot either, because it depends on the subjects' acts of judging; being in potency and in act isn't either because it derives from categorical being.

24 Brentano 1862/2015, 220/195. 
tion-that turns out to be quite close not only to that of Aquinas, but also, and to some extent only, to that of Ockham ${ }^{25}$-on the background of a discussion of Kant's and Hegel's interpretation of Aristotle (according to which the Stagirite offered nothing but a rhapsodic table of categories), but also in opposition to more contemporary views, such as Zeller's epistemological theory (categories are mere conceptual schemes) and Trendelenburg's logico-grammatical account (categories are the most general predicates).

Somewhat paradoxically, however, the most massive presence of medieval thought in the dissertation is an implicit or tacit one: it is found in chapter 3, dedicated to being in the sense of being true. As Antonelli and Sauer have convincingly demonstrated, Brentano proceeds here as a Thomist under cover, i.e. draped with the cloth of an Aristotle exegete ${ }^{26}$.

ii) The history of the ecclesiastic sciences. During his lifetime, Brentano published only one text wholly dedicated to medieval philosophy. It is the chapter of Möhler's Kirchengeschichte (1867), bearing the significant title: "Geschichte der kirchlichen Wissenschaften". Thus, the approach is explicitly both historical and religion-oriented.

The first of these two features has the (non-necessary but context-determined) effect of preventing the chapter to deal with just about any of the (many) philosophically interesting questions raised and discussed by medieval philosophers and theologians. Thus, regarding ontology, one finds nothing beyond expected mentions of different views on universals (Abelard, Ockham), an allusion to Duns Scotus' ("pernicious") invention of the formal distinction as intermediate between real and mere conceptual distinction, and one or two other points, all of which are merely touched upon ${ }^{27}$. Theo-

25 The idea that the deduction of the categories is "linguistic-based" is especially clear in the case of Ockham. Brentano refers to Ockham's Summa logicae I, c. 41, on the number of the categories (and not c. 42 as Brentano mistakenly writes). Antonelli and Sauer, in their introduction, p. XXXLVII-XXXLVIII, rightly quote c. 41, but do not correct Brentano's mistake in their edition. Brentano approves Ockham's claim that the categories are distinguished according to types of simple interrogative words (incomplexa such as quid, quantum, quale, etc.) on the base of which questions can be formulated with respect to primary substance: quid est?, quantum est?, quale est?, etc. The idea is the following: that by which one correctly answers the question quid est? is in the category of substance; that by which one correctly answers the question quantum est? is in the category of quantity, etc. Brentano agrees with Ockham insofar as he acknowledges a strong affinity (eine nicht geringe Verwandtschaft) between categories and certain linguistic expressions (Brentano 1862/2015, 185/167). He would, however, reject Ockham's reductionist program, according to which only substance, quality (and in some specific, theologically motivated cases, relation) are to be taken ontologically seriously (i.e. as being entities). Brentano would also reject Ockham's claim that substance and quantity are not distinct entities. As a matter of fact, when Brentano addresses the question of the rea identity between different categories (Brentano 1862/2015, V, \$10), he gives examples of action and passion, quantity and place, quantity and time, but not of substance and quantity, which he would certainly had done, if he had accepted Ockham's reductionist program.

26 Antonelli \& Sauer 2015, LXVIII-LXXVI. See also Sauer 2013, and the discussion below.

27 According to Brentano, Scotus, being an enthusiast and especially sharp critique of Aquinas, is wrong just about anywhere in his work. A notable (but philosophically irrelevant) exception is his acknowledgement of Mary's immaculate conception (i.e. not the fact that she got pregnant without losing her virginity, but that she did so without sin, a point in which Aquinas himself remained blind with respect to truth). logically relevant aspects are stressed, by contrast, such as the controversies about transubstantiation (Beranger of Tours vs. Lanfranc du Bec, in the $11^{\text {th }}$ c.), the concurrence between Dominicans and Franciscans in the late $13^{\text {th }}$ and $14^{\text {th }}$ centuries, but also the transepochal question of the relation between theology and philosophy (a challenging question which found its most convincing answer in Albertus Magnus' work and, even more, in that of his pupil, Thomas Aquinas).

As for the second feature, the religion-oriented character of the study, it comes to light in those (unfortunate) passages dealing with non-Christian (i.e. Arabic and Hebraic) thought, where Brentano writes with a clear (and tendencious) ideological agenda. Thus the implicature of Brentano's interpretation of the translatio studiorum: medieval Arab or Persian philosophers (Farabi, Avicenna, Averroes) came in possession of the treasures of Greek wisdom, and their unique role in the history of (and contribution to) philosophy is that of having been mere transmitters; or the characterisation of Aquinas' Summa contra gentiles as an apologetic work (which it definitely is not); but also, along the same line, the praise of Aquinas' thought for being "free of any Arabic coloration" (which, by the way, is patently false ${ }^{28}$.

Regardless of this last point, Brentano's chapter offers a decent, contemporary state of the art, mentioning the main schools, thinkers and institutions from the time of the encyclopaedist Isidor of Sevilla $\left(7^{\text {th }}\right.$ c.) to that of Nicolas of Cusa $\left(15^{\text {th }}\right.$ c.). We have to do with a useful compilation of information gathered in the major histories of medieval philosophy available around the middle of the $19^{\text {th }}$ century: Barthélémy Hauréau, De la philosophie scolastique (1850), Ernest Renan, Averroès et l'averroïsme (1852), Salomon Munk, Mélanges de philosophie juive et arabe (1859), Alfred Stöckl, Geschichte der Philosophie des Mittelalters (1864-1866), Friedrich Ueberweg, Grundriss der Geschichte der Philosophie $(1866)^{29}$

With respect to Brentano's conception of the history of philosophy, the chapter of 1867 offers the first published formulation of what will become Brentano's famous theory of the four phases in the history of philosophy. Thus, having reconstructed the history of the ecclesiastic sciences from the time of the emergence of medieval scholasticism with Anselm of Canterbury ( $11^{\text {th }} \mathrm{c}$.) to that of the reception of the whole of Aristotle's works (with their Arab interpretations), Brentano announces that four distinctive moments in the history of medieval philosophy are still to be considered: first, the time of further development of philosophy and theology under peripatetic influence up to its climax in the person and works of Aquinas; second, the fight of schools-Dominicans (followers of Albert and Aquinas) vs. Franciscans (followers of Bonaventure and of Duns Scotus)—-that initiated the decline; third, the time of nominalism and the associated scepticism (with Ockham and his followers); fourth 28 Brentano 1867, 540, 542, 555.

29 For Brentano's use of previous histories of philosophy, see Hedwig's Vorwort in Brentano 1980 (esp. p. XVII, n. 10). 
and finally, mysticism, as a "Surrogat der Wissenschaft" (with Eckhart, Gerson and Cusanus) ${ }^{30}$.

iii) The history of medieval philosophy. Hedwig's edition of Brentano's Geschichte der mittelalterlichen Philososphie im christlichen Abendlande is a careful text-(re)construction based on simple notes prepared by Brentano for a course given in 1870, on his chapter on ecclesiastic sciences (1867), and on sensible conjectures by the editor himself. Pace Hedwig, the history of medieval philosophy is not a mere elaboration of the chapter of $1867^{31}$. The later text differs from the earlier one in two respects. First, its perspective is consistently philosophicaltheology remains a topic, but one does not have to do any more with a religion-oriented account. Second, the later text repeatedly enters doctrinal grounds, something that was just about absent in the earlier one.

The introduction of the book consists in an application of the four phases model to the medieval period. However, it begins with an explanation that immediately reminds of the problematic ideological agenda that dominated the chapter of 1867: it is the Christian (i.e. roman-catholic) culture prevailing in western Europe after the fall of the Empire that created favourable conditions for a revival of scientific culture. That, Brentano claims, was not possible elsewhere, namely in the Byzantine, and the Islamic world ${ }^{32}$. The four phases are characterized as follows: $a$ ) development under pure, genuine, philosophical interest and natural (naturgemäss) method; b) decline by diminution and blurring of the philosophical interest, and thus, by growing quarrels, and hyper sophistication; $C$ ) nominalism and scepticism (the general claims that universals are nothing but signs, and that the object of scientific knowledge is nothing but a mental proposition blocks scientific realism and thus naturally leads to scepticism); d) mystic (over)reaction in the form of free-floating speculation. Applied to medieval philosophy, such a model yields the following periodisation: a) Anselm to Aquinas; b) after Aquinas and before Ockham; $c$ ) Ockham; d) Gerson to Cusanus.

With respect to Brentano's knowledge and use of medieval ontology, one issue among those addressed in the Geschichte der mittelalterlichen Philosophie stands out, namely that of universals. Universals are the only eponymous topic within that work: Das Universalienproblem is the only main section of the book named after a philosophical topic (all others main titles are either names of authors or historiographical categories, e.g. "Early Scholastic Authors"). The chapter, immediately following that on Anselm, deals with figures such as William of Champeaux, Abelard and Gilbert of Poitiers.

In a short introductory section, Brentano clarifies the notions of realism and nominalism. He begins by rightly distinguishing the medieval oppo-

30 Cf. Hedwig's Vorwort in Brentano 1980, esp. XII-XIII

31 Hedwig, Vorwort, in Brentano 1980, XII: “... die philosophische Wertung der einzelnen Sachprobleme und Epochen $<$ bleiben $>$ in beiden Texten gleich."

32 Brentano 1980, 1: "Die Araber, ein phantastisches Volk; zu nüchterner Betrachtung und Forschung nicht wie die Okzidentalen geeignet." sition that goes back to Porphyry's Isagoge ${ }^{33}$ from the opposition between Plato and Aristotle: "Der Gegensatz zwischen Nominalismus und Realismus war nicht ihr Gegensatz" ${ }^{34}$, meaning: both were realist (although not in the same way). The medieval doctrinal landscape is delineated by two extremes, both of which are mistaken: non-Platonic realism à la William of Champeaux (the "common man" is the one, identical, material essence of every single man, individuation being achieved by accidents only) ${ }^{35}$ on the one side, and a form of vocalism à la Roscelin of Compiègne (a universal is nothing but a flatus vocis, a vocal sound), on the other. Brentano's reconstruction also includes two moderate positions: conceptualism (on the side of nominalism), that takes universals to be mental items (they are said to be in intellectibus), and the kind of moderate realism that will be adopted in the $13^{\text {th }}$ century by Albert the Great and Aquinas ${ }^{36}$.

In a footnote of his edition, Hedwig remarks that Brentano here (as in 1867) directly depends on Stöckl who, in the corresponding passage-a passage underscored in Brentano's copy-, makes use of the notion of inexistence: "Es ist anzunehmen, dass Brentano den Begriff der 'Inexistenz' von Stöckl ... übernommen hat" ${ }^{37}$. It is well known, however, that when in the Psychologie of 1874 Brentano introduces inexistence, it is not in the context of the discussion of universals, but in order to provide mental phenomena with a satisfactory criterion of identification. Furthermore, Stöckl uses 'inexistence' in a sense that is precisely not the one Brentano will introduce. What Stöckl means is this: moderate realists distinguished between content ("Inhalt") and form of universals, located contents in re ("in der Objectivität"), and forms in intellectu ("in der Subjectivität"); now, the inexistence is that of the content of a universal in each individual of a given species ${ }^{38}$. Thus Stöckl's inexistence is not Brentano's, for the latter is mental while the former is not. That is not to say that Hedwig's remark is not useful, quite on the contrary: it could very well point towards a crucial reference when it comes to the question of the sources of Brentano's (later) ontology and, more precisely, both of his claim that there are non-real, immanent objects that "inexist" in the mind and that in addition to "real beings" (entia realia), one also finds "beings of reason" (entia rationis) in the outer world ${ }^{39}$.

33 On the problem of universals in Antiquity and the Middle Ages, see de Libera 2014.

34 Brentano 1980, 20.

35 On William of Champeaux's realism, see Erismann 2011

36 This is Brentano's favourite option (Brentano 1980, 19)—see also Brentano 1867, 532, n. 2. On that topic, see Chrudzimski 2004, 97.

37 Hedwig, in Brentano 1980, 107.

38 Stöckl 1864, 144: "Denn man gewann auf diesem Wege das Resultat, dass die Universalien nach ihrem Inhalte objectiv in den Dingen wirklich, dass sie nach diesem ihrem Inhalt nur der ideale Ausdruck des Wesens der individuellen Dinge seien; während sie dagegen die Form der Allgemeinheit, welche ihnen eigen ist, nur durch den denkenden Geist selbst erhalten, so jedoch, dass der Verstand hiebei nicht willkürlich zu Werke geht, sondern auf der Basis der Objectivität sich bewegt, sofern nämlich die wirkliche oder mögliche Inexistenz des Inhaltes eines Begriffes in einer Mehrheit von individuen für den Verstand der objective Grund ist, diese Individuen insgesamt und keine anderen, unter jenem Begriffe, welcher deren Wesen zum Inhalte hat, zusammenzufassen, und so jenen Begriff als allgemein geltend für alle diese Individuen zu denken."

39 Showing in detail how Stöckl may have influenced Brentano would 
In the following section, we aim at presenting the main notions in Brentano's own ontology, namely, 'reality', 'unreality', and 'being as true', which was equated for a while with 'existence'. We will trace them back to their medieval sources, not only by following Brentano's explicit references, but also on the basis of structural commonalities. It will allow us to evaluate the adequacy of Brentano's borrowings and, thus, to determinate to what extent Brentano's ontology is medieval.

\section{Brentano's main ontological notions and their medieval sources ${ }^{40}$}

\section{a. Realia}

The young Brentano, in his lectures on metaphysics given in Würzburg from 1867 onwards, says that in the "proper" (eigentlich) sense, "being" is restricted to "reality" $"$. The different sorts of realia are all beings in one and the same sense. In other words, 'being' applies to them, as A. Chrudzimski says, "synonymously" 42 . This is opposed to the view ascribed to Aristotle by Brentano in his dissertation, namely that 'being' in the sense of reality, i.e. "being according to the figures of the categories" (ôv $\kappa \alpha \tau \grave{\alpha}$ $\tau \grave{\alpha} \sigma \chi \eta ́ \mu \alpha \tau \alpha \tau \tilde{\omega} v \kappa \alpha \tau \eta \gamma o \rho t \tilde{\omega} v)$, is "homonym", but has a "unity of analogy"43. The notion of 'res', i.e. 'reality' or 'thing', is central in Brentano's ontology. In his lectures on metaphysics, Brentano holds that 'reality' is a primitive notion. Indeed, "we cannot define it, but explain it through examples (...)". The examples given by Brentano are: "human being, extended, here, now"44. Later on, Brentano will adopt another position, and undertake to explain the notion of reality. In 1899, during his maturity period, he says that a 'res' is something which has the ability to provoke or to suffer a causal influence. However, there are also items which are not causally efficacious and are, thus, 'irrealia' ${ }^{45}$. For Brentano, irrealia, although causally ine-

require an independent study. A sketch of a possible scenario would be the following: the application of the notion of inexistence to the philosophy of mind is indicated by Stöckl himself (and that might have contributed to inspire Brentano) when he writes that according to conceptualists universals "werden aus den Vorstellungen, welche die individuelle Form der Objecte repräsentiren, durch Entwicklung des Inhalts dieser Vorstellungen gewonnen" (Stöckl 1864, 145). Stöckl speaks of "presentations" (Vorstellungen), "concepts" (Begriffe) and "mental acts" (Acte des Verstandes), and says of both presentations and concepts that they have a content (Inhalt) - presumably the same, namely what "inexists" in the individuals of one species (see the text quoted in the previous footnote). Hence, the same "content" that exists in the individuals can also be found in the mind, i.e. it can also exist in the mind. On the other hand, that which is in the mind is exactly what one finds outside, i.e. its being in the mind does not forbid its being outside of it. Thus, the idea is that it could have been precisely that kind of association that led Brentano to talk of what is objectively in the mind as "inexisting" in it, and of what is outside as "beings of reason".

40 This section is not meant to be an exhaustive presentation of ontology or the notion of 'being' in the Middle Ages. We will only focus on the elements relevant for our comparison with Brentano.

41 See Brentano M 96, lect. XXXIX, quoted in Chrudzimski 2004, 79. Brentano's metaphysics lectures are not published, and we quote them following Chrudzimski 2004, who reproduces many passages. On these lectures, see also Baumgartner, Simons 1992-1993 and Baumgartner 2013.

42 Chrudzimski 2004, 115.

43 Brentano $1862 / 2015,85-98 / 84-94$. On the complex history of the notion of 'analogy', see Courtine 2005.

44 Brentano M 96, lect. XXXIX, quoted in Chrudzimski 2004, 79.

45 See Brentano 2013, 466-467 and, for a discussion, Chrudzimski 2004, 138-139. For the date of the text, see G. Fréchette's introduction in Brentano 2013. On these questions, see also Taieb 2017. fficacious, exist "in the outer world" (in der Außenwelt) ${ }^{46}$. By contrast, in Brentano's late ontology, the only items that are admitted are 'res' 47 . The late, so-called 'reistic' Brentano, when criticizing his own ontological acceptance of both realia and irrealia, held that his former theory had as a consequence that being was not "a unitary concept" (ein einheitlicher Begriff) ${ }^{48}$. Reism, and its "renunciation of the unreal", makes of 'being' a unitary concept. According to Brentano, this would not be an Aristotelian, but rather a Platonic position ${ }^{49}$. Indeed, 'being', in Aristotle, is not a genus, not even 'being according to the figures of the categories, ${ }^{50}$. The late Brentano seems to abandon his causal understanding of reality: 'reality' is not the "ability to be causally efficacious" (Wirkungsfähigkeit). He notably refers to Aquinas, who is meant to defend that "the concept of thing, of being in the sense of reality, is the one grasped by the intellect first in everything as the most general concept" ${ }^{\prime 51}$. Brentano does not explain why Aquinas' claim would forbid the identification of reality and causal efficacy. The idea is maybe that since in Aquinas' philosophy 'things' are members of Aristotle's categories, and since some 'things' are not concerned by causality, namely all the items that do not fall under the categories of 'action' and 'passion', the notion of 'thing' must be strictly taken apart from causality. At least, Brentano makes a similar claim as regards Aristotle's putative grounds for rejecting the identification of reality and causal efficacy: 'thing' concerns all categories, whereas "action" ( $\pi 01 \varepsilon i v)$ is just one of Aristotle's categories.

Concerning 'being according to the figures of the categories', or 'real being' (esse reale), many Scholastic thinkers were holding, like Brentano in his dissertation, that it has an "analogical unity". However, famously, Scotus defended that 'being' was a univocal concept when applied to the categories, even with respect to $\mathrm{God}^{52}$. This position is akin to that of Brentano himself, but who, however, was rarely mentioning Scotus as a reference. Although Brentano's views on reality as distinct from causal efficacy may find echoes in Aristotle and Aquinas, the idea that reality is connected to causality is also, to some extent, Aristotelico-Scholastic. First of all, Aristotle himself, in the Physics and the Metaphysics, holds that relations have less "being" (óv) than items in the other categories, and explains this by the fact that they can be acquired or lost without any change undergone by their bearer: something can become larger or smaller simply because something else has changed ${ }^{53}$. Thus, 'being' seems to be connected to the idea of change. This will be exploited in the Middle Ages. Indeed, Peter Auriol holds that relations are not "things" (res), because a 'thing' cannot be acquired without an "agent" (agens) "affecting" (attingere) its

\footnotetext{
46 Brentano 2013, 473.

47 See Brentano 1933

48 Brentano 1952, notably 260-263. On Brentano's late position, see also Brentano 1933. For a discussion of Brentano's reism, besides Chrudzimski 2004, see also Simons 1988.

49 See notably Brentano 1986, 190. The reference to Plato may be Sophist, 254d, where Plato holds that being is a genus

50 See also Chrudzimski 2004, 86.

51 Brentano 1930, 107-109 and 1952, 250-252. The references are probably Aquinas, De ente et essentia, prologue and ch. 1, as well as De veritate, q. 1 , a. 1 , resp.

52 On the notion of 'analogy', see again Courtine 2005. On the univocity of being, see notably Scotus, Ord. I, d. 3, p. 1 and d. 8, p. 1. For Scotus' claim that his views are compatible with Aristotle, see Scotus, Ord. I, d. 3, p. 1, q. $3, \mathrm{n}^{\circ} 152-166$.
}

53 See Aristotle, Met. N, 1, 1088a22-35 and Phys. V, 2, 225b11-13. 
bearer ${ }^{54}$. Among late Scholastic authors, one finds Suárez defending the view that "things" (res) are such entities that have causal powers ${ }^{55}$. Brentano was apparently aware of Suárez's views. Indeed, he holds that for Suárez, relations are not real "because they can be acquired or lost without the slightest change in the thing to which they belong" "56. As a matter of fact, this reason is mentioned by Suárez for rejecting the thesis that a relation is "really distinct" from its fundament ${ }^{57}$. Thus, Brentano's connexion between reality and causality has indeed Aristotelico-Scholastic sources.

\section{b. Irrealia}

In his metaphysics lectures, Brentano rejects that the idea that 'non-real' items, e.g. abstracta, negativa and privativa, "potentialia", mere intentional objects, "collectiva" and "divisiva", have some existence ${ }^{58}$. Later on, he changes his mind. Indeed, Brentano, in his maturity period, admits 'irrealia' in his ontology, including all the mentioned items ${ }^{59}$. An important class of irrealia is the one of abstracta, i.e. properties: Brentano holds that besides 'something red', the concretum, there is also 'redness' itself, an abstractum. Note that such properties can be either essential or accidental. However, Brentano considers that they are all particular. As a matter of fact, Brentano argues, all along his writings, against realism about universals $^{60}$. By contrast to realia, irrealia are not causally efficacious: they come into being or disappear when something else suffers a causal influence. For example, "a collective, a multitude of beings of the same kind, persisting independently of each other. When these are all causally brought about, the collective comes about along with them" ${ }^{61}$. This idea, for Brentano, would also have Suárezian origins: "With respect to the relationship between the ens rationis and the ens reale $<$ Suárez $>$ maintains that only when the latter are produced or destroyed are certain entia rationis brought about or destroyed concomitantly". 62

At any rate, as regards "beings" (Seiende), one must distinguish, on the one hand, realia and, on the other hand, irrealia. Thus, in that period, Brentano seems to admit that being has two proper, but radically distinct senses: real and unreal, i.e. Brentano admits two types of beings in his ontology. Note that Brentano sometimes also calls his irrealia 'entia rationis', i.e. 'beings of reason'. For example, borrowing a medieval vocabulary, he talks of some relations as "relations of reason" (relationes rationis). Yet he insist that one would better call them "non-subsistent"

\footnotetext{
54 Auriol, Scriptum, d. 30, p. 1, a. 2, ed. Roma, 671aA-E and 673bA, ms. Vat. Borgh. lat. 329, 322vb-323ra and 324ra.

55 See Suárez, DM XVIII, and the presentation in Schmid forthcoming.

56 Brentano 1925, 273.

57 Suárez, DM XLVII, 2, 13 and 22.

58 See Brentano M 96, lect. XXXVIII and XXXIX, as well as Chrudzimski 2004, 70-79.

59 For a more precise list of irrealia in Brentano, and detailed chronological information, see Chrudzimski 2004, 201-202.

60 For the distinction between essential and accidental properties, see notably Brentano 1992-1993. For Brentano's arguments against realism about universals, see notably Brentano 1925/2008, 137/393-394. For a discussion on whether Brentano manages to avoid, despite his own claims, universal properties, see Taieb 2017. On all these questions, see also Chrudzimski 2004.

61 Brentano 2013, 467, transl. Rollinger.

62 Brentano 1925, 273, transl. Rancurello, Terrell, McAlister. For the links between Brentano and Suárez on beings of reason, see Boccaccini 2010 .
}

(unwesenhafte) relations, which is equivalent to 'unreal' ${ }^{63}$. As a matter of fact, "irrealia' exist "in the outer world" However, the ambiguity in the vocabulary is meant to be firmly rooted in Scholastic philosophy. As Brentano says: "The distinction we made above between effective and non-effective being corresponds to the one the Scholastics have made between ens reale and ens rationis". ${ }^{65}$

Yet, Brentano immediately adds: "However, it also seems to me that they have often used the expression 'ens rationis' for the non-being to the extent that it can be the object of a psychic activity, the one of thinking". ${ }^{66}$

Although 'being of reason' is not a name used by Aristotle himself, Brentano claims that irrealia would be dependent upon two places in the Aristotelian corpus, both in the Metaphysics: a passage where Aristotle holds that "health" is "in the soul" of the doctor, and another text, where, talking of the relations between cognitive acts and their objects, Aristotle holds that the object is not related by itself to the act, but because the act is related to $i^{67}$.

As regards Aristotle, Brentano does not explain to what extent the passage holding of health that it is "in the soul" differs from other passages in which Aristotle talks of items "in the soul", for example a famous statement in the De anima that universals are intra-psychic, not to mention the fact that 'health', although "in the soul", has a real counterpart in reality, namely 'health' as a disposition, which is a species of quality ${ }^{68}$. Is Brentano simply saying that all conceptual contents are 'beings of reason' for Aristotle? As regards the mentioned passage on relations in Aristotle, it is quite obscure. According to its medieval exegesis, what Aristotle means is that the relation from the cognitive act to the object is real, whereas there is no real relation in the object. Yet, since the intellect cannot think of something related to something else without thinking of a converse relation, it 'puts' a relation into the object. In that sense, the relation in question is a "relation of reason" (relatio rationis) ${ }^{69}$. Thus, Brentano's reading of Aristotle is strongly based on the medieval reception of the Metaphysics. As Suárez points out, Scholastic authors, notably Aquinas, did develop theories of 'beings of reason', a class of items including not only 'relations', but also 'negations' and 'privations ${ }^{70}$. However, these items where not meant to stay "in the outer world" (in der Außenwelt). Aquinas, for example, is quite clear on the fact that a being of reason is "in reason" (in ratione) ${ }^{71}$. Similarly, Suárez holds that 'beings of reason' have only "objective being", i.e. they exist only to the extent that they are thou-

\footnotetext{
63 Brentano 2013, 470.

64 Brentano 2013, 473.

65 Brentano, Ps 34, Von den Relationen, n`51076: "Den Unterschied den wir oben zwischen wirklichen und unwirklichen Seienden machten, entspricht dem, welchem die Scholastiker zwischen ens reale und ens rationis machten" (Brentano's emphasis). In view of the proximity between this passage and Brentano 2013, both texts must be of the same period, namely around 1890 (see Fréchette 2013, 421 for the date of Brentano 2013).

66 Brentano, Ps 34, Von den Relationen, n51076: "Doch scheinen mir diese den Ausdruck 'ens rationis' oft auch auf Nicht-seiendes, sofern es Gegenstand einer psychischen Tätigkeit, des des Denkens, werden kann, angewendet zu haben" (Brentano's emphasis).

67 Brentano 1925,272 n. 1 and Aristotle, Met. $\Delta, 15,1021 \mathrm{a} 26-1021 \mathrm{~b} 2$ and Z, 7, 1032a25-1033a5.

68 See Aristotle, De anima II, 5, 417b22-24 and Cat. VIII, 8b35-9a1.

69 On this medieval reading, which amounts to admitting "non-mutual" (non mutua) relations, see Henninger 1989.

70 See Suárez, DM XLIV, 3, 1 and notably the reference to Aquinas, De veritate, q. 21, a. 1 , resp.

71 Aquinas, De veritate, q. 21, a. 1, resp. and In Met., IV, 1. 1, n. 540.
} 
ght-of ${ }^{72}$. To be sure, a being of reason can have a "foundation in reality" (fundamentum in re), as Suárez insists. For example, to blindness taken as something "positive", i.e. a being of reason, corresponds the "negative" lack of sight in the outer world ${ }^{73}$. But it is something quite distinct to have a foundation in the outer world and to exist in the outer world. Besides, Suárez does affirm that 'beings of reason' appear "concomitantly" to real beings. However, his point is different from Brentano's. Indeed, Suárez's affirmation does not lead to admit extra-psychic beings of reason, for example an army being there when soldiers appear. For Suárez, the real beings concomitantly to which beings of reason appear are exclusively psychic items, more precisely mental acts: no being of reason can appear without a mental act of which it is the object ${ }^{74}$. Thus, Suárez's claim does not make Brentano's point that beings of reason are "in the outer world". Brentano himself probably realized that his theory of mind-independent irrealia was not strictly Scholastic. At any rate, on the way to his reistic position, one finds him admitting that irrealia, i.e. the items corresponding to the Scholastic "beings of reason' (entia rationis), are merely "in the soul". Indeed, Brentano says that the "concept" (Begriff) of such items always contains an "intentional moment" (intentionales Moment $)^{75}$. Thus, in the final analysis, Brentano does not hold that 'mere intentional objects' are a kind of irreale, but that all irrealia are 'mere intentional objects'. This is indeed a Scholastic position. In order to understand how the pre-reistic Brentano arrived to this conflict with the Scholastics on irrealia, one must consider his interpretation of the notion of 'being as true'.

\section{c. Being as true}

Brentano borrows the notion of 'being as true' (ôv $\mathfrak{\text { c }}$ $\dot{\alpha} \lambda \eta \theta \dot{\varepsilon} \zeta^{\prime}$ from Aristotle. In his dissertation, Brentano holds that "being true" and "being false" concern "judgments" However, he also extends the meaning of 'being as true' to "concepts" (Begriffe). More precisely, Brentano says that "every thought-of thing (Gedankending), i.e. everything that can be subject of a true affirmative statement to the extent that it exists objectively in our mind" has "being as true" "77. In that context, he refers to a passage of Metaphy$\operatorname{sics} \Delta, 12$ were Aristotle holds that in a sense, even privativa are a "having" ("̋ $\xi 1 \zeta$ ), or a "property" (Eigenschaft), as Brentano translates it, i.e. a "positive state" (positiver Zustand), and that "being" ( $\tau$ ò öv) is said "homonymously" (ó $\mu \omega v v \omega \omega \varsigma)$, which may indicate that such items have 'being as true"78. Now, this sense of being, in Brentano's dissertation, is said to be "improper" (uneigentlich), just as 'being according to accident' (ôv $\kappa \alpha \tau \alpha ̀ ~ \sigma \nu \mu \beta \varepsilon \beta \eta \kappa o ́ \varsigma){ }^{79}$. As W. Sauer has shown, if Brentano extends 'being as true' from judgments to concepts, it is because he equates

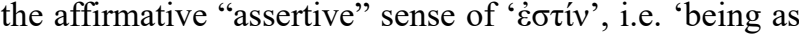

72 Suárez, DM XLIV, 1, 4-7.

73 Suárez, DM XLIV , 3, 4 and 4,2.

74 Suárez, DM XLIV, 4.

75 Brentano, Letter to Marty, 24 November 1893, quoted in Chrudzimski 2004, 199. See also Brentano, T S 14, Realität und Intensionalität. (Neue Theorie der Zeit, Neue Theorie der Relation), n'85283, quoted in Chrudzimski 2004, 199.

76 Brentano 1862/2015, 33-37/38-42.

77 Brentano 1862/2015, 37-38/42-44.

78 Aristotle, Met. $\Delta, 12,1019 \mathrm{~b} 6-8$, transl. Ross.

79 Brentano 1862/2015, 21/28 and 38-39/43-44. See also Brentano 1986 190-191. true', and the positive copula ${ }^{80}$. Aristotle, in Metaphysics $\Delta, 7$ and E, 4, holds that 'being as true' applies to judgments, namely to those that are true: "falsity and truth are not in things (...), but in thought" $"$. Indeed, the Greeks were using ' $\varepsilon \sigma \tau$ ' $v$ ' followed by a proposition to say of the content of the proposition that "it is true". Similarly, in German, to a question like: "Nicht wahr, kein Radius ist dem andern ungleich?", one may answer "so ist es"82. Yet, at least since Alexander of Aphrodisias, some readers of Aristotle superimposed this affirmative 'assertive' sense of 'is' and the positive copula, as well as the negative 'assertive' sense of 'is not', i.e. 'is false', and the negative copula $^{83}$. For Aquinas, even the "est" in existential propositions such as "there is God" (Deus est) may be the 'est' of 'being as true" ${ }^{84}$. Brentano explicitly relies on such hermeneutical choices ${ }^{85}$. However, his extension of "being as true' from judgments to "every thought-of thing" does not yet entail that these 'thought-of things' exist. Indeed, in his metaphysics lectures, Brentano says that 'non-real' items have 'being as true', but seems to reject the idea that this sense of being has any ontological commitment ${ }^{86}$. Yet he will change his mind later on. Indeed, he will hold that 'being as true' equates 'existence': "ôv $\omega \varsigma \alpha \hat{\alpha} \lambda \eta \theta \dot{\varepsilon} \varsigma$, i.e. in the sense of the existent" $"$. As a matter of fact, according to Brentano, 'existence' is a concept that one acquires by reflecting upon one's own judgments, "something existent" meaning "everything for which the acknowledging judgment is true" 88 . As W. Sauer summarizes Brentano's evolution:

(...) since das Sein der Kopula, which was in turn equated with veridical Be, was now ascribed to the subject of a true affirmation, that subject too came to be subsumed under the notion of being as the true, and since being in the sense of what exists is that about which a true affirmation can be formed, being in the sense of what exists came to be equated with being as true. ${ }^{89}$

On such a view, since someone judging 'there is a privation' may judge truly, it entails that privations can exist ${ }^{90}$. In other words, 'being as true' understood as 'existence' may equally apply to realia and irrealia. This seems to be what lead Brentano, in his later works, to admit irrealia in his ontology and, thus, to modify his position: just as realia, irrealia exist "in the outer world" (in der Außenwel-

\footnotetext{
80 Sauer 2013.

81 Aristotle, Met. E, 4, 1027b25-27, transl. Ross

82 See Brentano 1986, 190-191.

83 On this point, we follow the detailed analysis found in Sauer 2013. See also Antonelli, Sauer 2015

84 See Aquinas, STh Ia , q. 3, a. 4, ad 2, discussed in Sauer 2013

85 See the reference to Alexander in Brentano 1862/2015, 35-36/40-41, and the references to Aquinas in Brentano 1930, 128-129 and 162-163 (Brentano 1930, 162-164 is not a text of Brentano, but a record by A. Kastil of a discussion with Brentano), as well as Brentano 1952, 291-292.

86 See Brentano M 96, lect. XXXVIII and XXXIX, as well as XXVI and XLIII, all quoted and discussed in Chrudzimski 2004. As Chrudzimski 2004, 71 says, in Brentano, M 96, lect. XXXVIII, 'being as true' belongs to "everything which can be subject or predicate of a true affirmative statement", which is different from the position defended in the dissertation.

87 Brentano 1930, 48, quoted in Sauer 2013, 194.

88 Brentano 1930, 45-46. On these points, see again Sauer 2013.

89 Sauer 2013, 225.

90 See Brentano 1930, 162-164.
} 
$t)^{91}$. During reism, Brentano comes back to his former views in holding that irrealia are beings in an "improper" sense. As regards 'being as true', he restricts it to judgment contents, which in turn are brought back to real thinkers judging in such and such a way, i.e. 'such and such a judgment content is (true)' = 'someone judging in such and such a way judges correctly'. The 'is' of “Socrates is” expresses the acknowledgment of Socrates, whereas the second 'is' in "That it is impossible, is", i.e. 'being as true', does not express the acknowledgement of 'that it is impossible, ${ }^{\text {92 }}$. One of the late Brentano's favourite activities is to list the different improper senses of being: e.g. "abstract being”, "intentional being”, "possible being", "past” and "future being”, but also "being as true" 93

One could convincingly argue that in Aristotle, 'being as true' is not a mode of being, but that

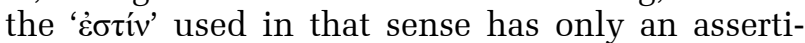
ve force, as the reistic Brentano himself finally defends. Besides, concerning Metaphysics $\Delta$, 12, were privativa are understood in terms of a "having", this passage, according to recent critical editions, does not mention the homonymy of "being", but of

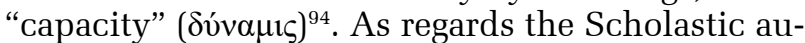
thors, willing to base themselves on Aristotle, they were distinguishing 'being according to the figures of the categories', or "real being" (esse reale), and "being as true" (esse ut verum). Aquinas, in his De ente et essentia, refers to Metaphysics $\Delta, 7$ and contrasts these two senses of 'being'. Whereas the first "puts something in the things" (in re ponit), it is not the case of the second, which concerns "everything about which an affirmative proposition can be formed”, including negativa and privativa ${ }^{95}$. This is almost verbatim Brentano's point in the dissertation. On such a basis, Aquinas can say that blindness has 'being as true' since "there is blindness", i.e. "blindness is", is true ${ }^{96}$. Apparently, the subject of a proposition in which 'is' stands for 'being as true' acquires 'being as true'. Besides, Aquinas seems to mean that 'being as true' is a mode of being, although given only "in reason" (in ratione). To that extent, even negativa and privativa are "beings" (entia) ${ }^{97}$. However, since such 'beings of reason', for Aquinas, are 'in the soul', not outside, they does not exist in the same manner as real things, i.e. real things have full-fledged existence, not these 'rational' items, which exist, as G. Klima says, in a "second sense"98. Contrarily to Brentano, Aquinas never assimilated the standard sense of 'existence' with 'being as true'. This seems to be admitted by Brentano himself, who holds that Aquinas contrasts "the real existence of God" (die reale Existenz Gottes) and

91 Brentano 2013, 473.

92 Brentano 1930, 162-164.

93 See for example Brentano 1933, 4-11 (although Kastil's edition is not always reliable, this passage is faithful to the original manuscript, i.e. M 77, Weisheit. Seiendes im eigentlichen und uneigentlichen Sinne, $\mathrm{n}^{\circ} 30842-$ 30853).

94 See Aristotle, Met. $\Delta, 12,1019 \mathrm{~b} 6-8$, ed. Ross and Jaeger, transl. Ross.

95 Aquinas, De ente et essentia, ch. 1.

96 Aquinas, In Met., V, 1. 9, n. 896.

97 Aquinas, In Met., IV, 1. 1, n. 540 and V, 1. 9, n. 896.

98 See Klima 1993, notably 29 and 30. his 'being as true'99. Following Aquinas, Scholastic authors were distinguishing 'being according to the figures of the categories', or 'real being', and 'being as true', which was also called "being in the soul" (esse in anima) or "being of reason" (esse rationis). Indeed, for the Scholastics, the Aristotelian loci classici for the admission of 'being in the soul' was Metaphysics $\Delta, 7$ and E, 4. One finds for example Scotus referring to "Metaphysics VI", i.e. 'E', when talking of intentional objects as items with a peculiar, "diminished" (deminutum) mode of being ${ }^{100}$. More explicitly, Franciscus de Prato writes:

(...) the Philosopher, in the $\mathrm{V}^{\text {th }}$ and $\mathrm{VI}^{\text {th }}$ books of the Metaphysics, (...) divides being according to its current meaning (communiter dictum) in being in the soul and being outside the soul, and with 'being in the soul', all philosophers and doctors mean 'being of reason', and with 'being outside the soul', they mean 'real being'. ${ }^{101}$

As Prato's master, Hervaeus Nathalis, states, "being", when divided in "real being" and "being of reason", is "equivocal" (equivocum). However, Hervaeus seems to admit that 'being of reason' is ontologically committing ${ }^{102}$. Thus, his position is akin to that of Aquinas, i.e. 'being of reason' gives some sort of existence, but in a "second sense". In sum, it was usual, for Scholastic authors, to distinguish two senses of being: 'being according to the figures of the categories', i.e. 'real being', and 'being as true', also labelled 'being in the soul' or 'being of reason'. To be sure, the Scholastics were not equating 'being as true' with 'existence' in the standard sense. Yet, like the later, but pre-reistic Brentano, the 'non-real' sense of 'being', for some Scholastic thinkers, was ontologically committing. However, importantly, such 'being' concerned things "in the soul" (in anima), not outside. In other words, whereas for Brentano, both realia and irrealia had 'existence' understood as 'being as true', and were found "in the outer world", for the Scholastics, only realia had full-fledged, extra-psychic existence, whereas irrealia were "in the soul" with 'being as true'. This is a major discrepancy between Brentano's views and the Scholastic ontological positions.

\section{Conclusion: Is Brentano's Ontology Medieval?}

Brentano's attachment to medieval philosophy does not come from a purely theoretical interest, but also has its origin in his Catholic faith. One could maybe even say that Brentano initially followed the Scholastics by vocation. However, his abandonment of priesthood did not entail a rejection of medieval philosophy. On the contrary, Brentano continued to think with Aquinas and other Scholastic authors until his late works. Beyond 99 See Aquinas, STh I', q. 3, a. 4, ad 2 and Brentano 1930, 162. In opposing Aquinas and Brentano on these questions, we partly distance ourselves from Sauer 2013

100 Duns Scotus, Lect. I, d. 36, §26. On 'diminished being', see Maurer 1950.

101 Franciscus de Prato, Tractatus de ente rationis, 286-287.

102 See Hervaeus Natalis, De Secundis Intentionibus, q. 5, a. 1, ed. Doyle, 537 , as well as Taieb 2015 . 
medieval philosophers, and even beyond Aristotle, Brentano was also strongly influenced by Early Modern thought, above all by Descartes, and gave lectures on this period as well (see Brentano 1987). However, since every period in the history of philosophy has its specificities, one could expect to find topics more thoroughly discussed by medieval thinkers than by authors belonging to any other period. Ontology surely is one of those topics: medieval philosophers engaged in detailed analyses on being, not only under the pressure of Aristotle's philosophy - whose categorial ontology is an invitation to provide the exact and exhaustive catalogue of the "furniture of the world" -, but also due to theological issues, including the question of the univocity (or equivocity) of being (i.e. of being said of God and its creatures) and the question of Trinitarian relations. Brentano, himself a specialist of the history of philosophy, knew where to search for first-hand theoretical material in ontology.

Now, the general picture that emerges from the inquires above on the relation between Brentano's theory and medieval ontology is quite complex. Indeed, Brentano describes some elements of his ontology as being Aristotelico-Scholastic, whereas they seem rather to be of his own invention, e.g. his assimilation of being as true with existence, or his account of entia rationis as mind-independent items. On these precise questions, Brentano apparently realised that he was taking a problematic path: finally, he holds that Aristotle's being as true has only an assertive force, and that beings of reason all contain an "intentional moment". This indicates that some elements taken by Brentano to be Aristotelico-Scholastic were (supposedly) borrowed from the past after having been put there... by Brentano himself ! To what extent such a problem can be avoided is an open question. To be sure, it goes beyond Brentano's relation, or ours, to medieval philosophy, and is a general (or maybe the general) problem in philosophy of the history of philosophy. But this problem was not at the core of Brentano's own methodological inquiries.

\section{Bibliography}

\section{a. Primary Sources}

Aristotle (1831), Opera, ed. E. Bekker, 2 vol., Berlin: Reimer.

- (1924), Metaphysics, ed. W. D. Ross, Oxford: Oxford University Press.

- (1957), Metaphysica, ed. W. Jaeger, Oxford: Oxford University Press.

- (1995), The Complete Works of Aristotle. The Revised Oxford Translation, ed. J. Barnes, 2 vol., Princeton, New Jersey: Princeton University Press.

Brentano F. (1862/2015), Von der mannigfachen Bedeutung des Seienden nach Aristoteles, Freiburg: Herder; $2^{\text {nd }}$ ed., ed. M. Antonelli, W. Sauer, Berlin: de Gruyter.
- (1867), "Geschichte der kirchlichen Wissenschaften", in Möhler J. A. (ed.), Kirchengeschichte, vol. 2, Regensburg: Georg Joseph Mans, p. 526-584, vol. 3, p. 103-104.

- (1876), Was für ein Philosoph manchmal Epoche macht, Wien: Hartlebens Verlag.

- (1895/1968), Die vier Phasen der Philosophie und ihr augenblicklicher Stand, Stuttgart: Johann F. Cotta Verlag; $2^{\text {nd }}$ ed. in Brentano F., Die vier Phasen der Philosophie und ihr augenblicklicher Stand. Nebst Abhandlungen über Plotinus, Thomas von Aquin, Kant, Schopenhauer und Auguste Comte, ed. O. Kraus, Hamburg: Felix Meiner Verlag, p. 1-32.

- (1925/2008), Von der Klassifikation der psychischen Phänomene, Psychologie vom empirischen Standpunkt, vol. 2, Leipzig: Duncker \& Humblot, 1911; $2^{\text {nd }}$ ed., ed. O. Kraus, Leipzig: Felix Meiner Verlag; $3^{\text {rd }}$ ed., A. Chrudzimski, Th. Binder, Frankfurt: Ontos Verlag; (1973), Psychology from an Empirical Standpoint, transl. A.C. Rancurello, D.B. Terrell, L.L. McAlister, London: Routledge.

- (1929), Über die Zukunft der Philosophie, nebst den Vorträgen Über die Gründe der Entmutigung auf philosophischem Gebiet, Über Schellings System sowie den 25 Habilitationsthesen, ed. O. Kraus, Leipzig: Felix Meiner Verlag.

- (1930), Wahrheit und Evidenz, ed. O. Kraus, Leipzig: Felix Meiner Verlag.

- (1933), Kategorienlehre, ed. A. Kastil, Leipzig: Felix Meiner Verlag.

- (1952), Die Abkehr vom Nichtrealen, ed. F. Mayer-Hillebrand, Berne: Francke.

- (1980), Geschichte der mittelalterlichen Philosophie im christlichen Abendland, ed. K. Hedwig, Hamburg: Felix Meiner Verlag.

- (1986), Über Aristoteles, ed. R. George, Hamburg: Felix Meiner Verlag.

- (1987), Geschichte der Philosophie der Neuzeit, ed. K. Hedwig, Hamburg: Felix Meiner Verlag.

-(1992-1993), "Zur Kategorienlehre”, ed. M. Antonelli, Brentano Studien 4, p. 251-270.

- (2013), "Abstraction und Relation", ed. G. Fréchette, in Fisette D., Fréchette G. (eds.), Themes from Brentano, Amsterdam: Rodopi, p. 465-482; "Abstraction and Relation", transl. R. Rollinger, in Fisette D., Fréchette G. (eds.), Themes from Brentano, Amsterdam: Rodopi, p. 431-447.

-, M 77, Weisheit. Seiendes im eigentlichen und uneigentlichen Sinne, 1914, Franz Clemens Brentano Compositions (MS Ger 230), Houghton Library, Harvard University.

-, M 96, Ontologie (Metaphysik), Franz Clemens Brentano Compositions (MS Ger 230), Houghton Library, Harvard University.

-, Ps 34, Von den Relationen, partly dated from 1908, Franz Clemens Brentano Compositions (MS Ger 230), Houghton Library, Harvard University. 
-, T S 14, Realität und Intensionalität. (Neue Theorie der Zeit, Neue Theorie der Relation), Franz Clemens Brentano Compositions (MS Ger 230), Houghton Library, Harvard University.

-, Letter to Marty, 24 November 1893.

Franciscus de Prato (2009), Tractatus de ente rationis, ed. F. Amerini, C. Rode, Archives d'histoire doctrinale et littéraire du Moyen âge 76, p. 261-312.

Hervaeus Natalis (2008), On Second Intentions, ed. and transl. J. P. Doyle, Milwaukee, Wisconsin: Marquette University Press.

John Duns Scotus (1950-), Opera Omnia, ed. Commissio Scotistica, 19 vol., Civitas Vaticana: Typis Polyglottis Vaticanis.

Peter Auriol, Scriptum super primum librum sententiarum, Ms. Vat. Borgh. lat. 329.

- (1596), Commentariorum in primum librum Sententiarum. Pars Prima. (Scriptum), Roma.

Plato (1900-1907), Opera, ed. J. Burnet, 4 vol., Oxford: Oxford University Press.

Suárez F. (1856-1877), Opera Omnia, 28 vol., Paris: Vivès (Disputationes Metaphysicae, vol. 25-26, reprint: Hildesheim: Olms, 1965).

-, Disputationes Metaphysicae, ed. S. Castellote, M. Renemann,

http://homepage.ruhr-uni-bochum.de/michael.renemann/suarez/ index.html.

Thomas Aquinas (1903-1906), Summa Theologiae, Opera Omnia t. IV-XII, Léonine, Roma: Ex Typographia Polyglotta S. C. de Propaganda Fide.

- (1961), Summa contra Gentiles, ed. C. Pera, P. Marc, P. Caramello, Torino - Roma: Marietti.

- (1976), De ente et essentia, ed. H. F. Dondaine, Opera Omnia t. XLIII, Opuscula, vol. IV, Léonine, Roma: Editori di San Tommaso.

- (1970-1976), Quaestiones disputatae De veritate, ed. A. Dondaine, 3 vol., Opera Omnia t. XXII, Léonine, Roma - Paris: Commissio Leonina - Éditions du Cerf.

- (1971), In duodecim libros Metaphysicorum Aristotelis expositio, ed. M. R. Cathala, R. M. Spiazzi, $2^{\text {nd }}$ ed., Torino Roma: Marietti.

\section{b. Secondary Literature}

Antonelli M. (2001), Seiendes, Bewusstsein, Intentionalität im Frühwerk von Franz Brentano, Freiburg i. Br. - München: Alber.

Antonelli M., Sauer W. (2015), "Einleitung”, in Brentano F., Von der mannigfachen Bedeutung des Seienden nach Aristoteles, Berlin: de Gruyter, p. XI-XCI.
Baumgartner W. (2013), "Franz Brentano's Mereology", in Fisette D., Fréchette G. (eds), Themes from Brentano, Amsterdam: Rodopi, p. 227-245.

Baumgartner W., Burkard F.-P. (1990), "Franz Brentano. Eine Skizze seines Lebens und seiner Werke", in International Bibliography of Austrian Philosophy (IBÖP), compiled with the assistance of Th. Binder, J. Valent, H. Werba, Amsterdam: Rodopi, p. 17-53.

Baumgartner W., Simons P. (1992-1993), "Brentanos Mereologie”, Brentano Studien 4, p. 53-77.

Boccaccini F. (2010), "Quasi umbræ entium. Suárez e Brentano sull'ens rationis”, in Sgarbi M. (ed.), Francisco Suárez and His Legacy. The Impact of Suarezian Metaphysics and Epistemology on Modern Philosophy, Milano: Vita e pensiero, p. 271-294.

Coreth E. (1988), "Schulrichtungen neuscholastischer Philosophie”, in Id., Neidl W. M., Pfligersdorfer G. (eds.), Christliche Philosophie im katholischen Denken des 19. u. 20. Jahrhunderts, vol. 2, Graz: Styria Verlag, p. 131-194.

Chrudzimski A. (2004), Die ontologie Franz Brentanos, Dordrecht: Kluwer Academic Publishers.

Courtine J.-F. (2005), Inventio analogiae. Métaphysique et ontothéologie, Paris: Vrin.

Erismann Ch. (2011), L'homme commun. La genèse du réalisme ontologique durant le haut Moyen Âge, Paris: Vrin.

Gilson E. (1939), “Franz Brentano’s Interpretation of Medieval Philosophy”, Mediaeval Studies 1, p. 1-10 (reprint in McAlister L. L. (ed.), The Philosophy of Brentano, London: Duckworth 1976, p. 56-67).

Hedwig K. (1978), "Der scholastische Kontext des Intentionalen bei Brentano", in Chisholm R. M., Haller R. (eds.), Die Philosophie Franz Brentanos (Grazer Philosophische Studien 5), Amsterdam: Rodopi, p. 67-82.

- (1979), "Intention: Outlines for the History of a Phenomenological Concept", Philosophy and Phenomenological Research 39, p. 326-340.

- (1992), "Über die moderne Rezeption der Intentionalität Thomas-Ockham-Brentano”, in Follon J., McEvoy J. (eds.), Finalité et intentionnalité : Doctrine thomiste et perspectives modernes. Actes du colloque de Louvain-la-Neuve et Louvain. 21-23 mai 1990, Louvain-la-Neuve - Paris - Leuven: Institut supérieur de philosophie - Vrin - Peeters, p. 211-235.

- (2012), ““...Eine gewisse Kongenialität’. Brentanos Rückgriff auf Thomas von Aquin in seiner Dissertation”, in Tănăsescu I. (ed.), Franz Brentano's Metaphysics and Psychology, Bucharest: Zeta Books, p. 95-131.

Henninger M. (1989), Relations. Medieval Theories 1250 1325, Oxford: Clarendon Press. 
Klima G. (1993), “The Changing Role of 'Entia Rationis' in Mediaeval Semantics and Ontology: A Comparative Study with a Reconstruction”, Synthese 96, p. 25-58.

Kluxen W. (1988), "Die geschichtliche Erforschung der mittelalterlichen Philosophie und die Neuscholastik", in Coreth E., Neidl W. M., Pfligersdorfer G. (eds.), Christliche Philosophie im katholischen Denken des 19. u. 20. Jahrhunderts, vol. 2, Graz: Styria Verlag, p. 362-389.

Kraus O. (1976), "Biographical Sketch of Franz Brentano", in McAlister L. L. (ed.), The Philosophy of Brentano, London: Duckworth, p. 1-9.

Libera A. de (2007), Archéologie du sujet, t. I : Naissance du sujet, Paris: Vrin.

- (2008), Archéologie du sujet, t. II : La quête de l'identité, Paris: Vrin.

- (2011), "Le direct et l'oblique : sur quelques aspects antiques et médiévaux de la théorie brentanienne des relatifs", in Reboul A. (ed.), Philosophical papers dedicated to Kevin Mulligan, Genève, http://www.philosophie.ch/kevin/ festschrift/.

- (2014), La querelle des universaux. De Platon à la fin du Moyen Âge, $2^{\text {nd }}$ ed., Le Seuil, Paris.

Marras A. (1974), “The Scholastic Roots of Brentano's Conception of Intentionality”, Rassegna di Scienze Filosofiche 1, p. 213-226 (reprint in McAlister L. L. (ed.), The Philosophy of Brentano, Duckworth, London 1976, p. 128-139).

Maurer A. (1950), “'Ens diminutum': A Note on its Origin and Meaning", Mediaeval Studies 12, p. 216-222.

McDonnell C. (2006a), “Brentano's Revaluation of the Scholastic Concept of Intentionality into a Root-Concept of Descriptive Psychology", Yearbook of the Irish Philosophical Society, Maynooth: National University of Ireland, Maynooth, p. 124-171.

- (2006b), "Brentano's Modification of the Medieval-Scholastic Concept of 'Intentional Inexistence' in Psychology from an Empirical Standpoint (1874)", Maynooth Philosophical Papers 3, p. 56-75.

Münch D. (2004), "Franz Brentano et la réception catholique d'Aristote au XIX siècle", in Thouard D. (ed.), Aristote au XIX $X^{e}$ siècle, Villeneuve d'Ascq: Presses universitaires du Septentrion, p. 231-248.

Nettesheim J. (1962), “Christoph Bernhard Schlüter und Franz Brentano", Zeitschrift für philosophische Forschung 16/2, p. 284-296 [contains 2 letters of Brentano to Ch. B. Schlüter from 1861 and 1863].

Perler D. (2002), Theorien der Intentionalität im Mittelalter, $2^{\text {nd }}$ ed., Frankfurt am Main: Vittorio Klostermann Verlag.

Schmid S. (forthcoming), Suárez's Metaphysics of Modalities.

Simons P. (1988), "Brentano's Theory of Categories: a Critical Appraisal”, Brentano Studien 1, p. 47-61.
Spiegelberg H. (1936), "Der Begriff der Intentionalität in der Scholastik, bei Brentano und Husserl”, Philosophische Hefte 5, p. 75-91 (reprint in Studia Philosophica 29 (1970), p. 189-216).

- (1976), “'Intention' and 'Intentionality' in the Scholastics, Brentano and Husserl”, in McAlister L. L. (ed.), The Philosophy of Brentano, London: Duckworth, p. 108-127.

Stöckl A. (1864-1866), Geschichte der Philosophie des Mittelalters, 3 vol., Franz Kirchheim Verlag, Mainz.

Taieb H. (2015), “The 'Intellected Thing' (res intellecta) in Hervaeus Nathalis", Vivarium 53, p. 26-44.

- (2017), "Brentano on Properties and Relations", in Kriegel U. (ed.), Routledge Handbook of Franz Brentano and the Brentano School, London: Routledge.

Walter P. (1988), "Die neuscholatische Philosophie im deutschsprachigen Raum", in Coreth E., Neidl W. M., Pfligersdorfer G. (eds.), Christliche Philosophie im katholischen Denken des 19. u. 20. Jahrhunderts, vol. 2, Graz: Styria Verlag, p. 131-194.

Laurent Cesalli is Professor for Medieval Philosophy at the University of Geneva. His research focuses on issues pertaining to philosophy of language, philosophy of mind and metaphysics in the medieval and Austro-German traditions. Email: laurent.cesalli@unige.ch

Hamid Taieb is a Postdoctoral Researcher at the University of Salzburg. He works on Austro-German philosophy and on the Aristotelian tradition, especially Latin scholasticism. Email: hamid.taieb@sbg.ac.at

Received 2018.01.28

Accepted 2018.08.02 